\title{
Optimization of Bioethanol Production from Cassava Peels
}

\author{
OSEMWENGIE, SO*; OSAGIE, EI; ONWUKWE, B \\ Department of Chemical Engineering, University of Benin, Benin City, PMB 1154, Nigeria \\ * Corresponding author Email: saint.osemwengie@uniben.edu
}

\begin{abstract}
The bioethanol production from waste is acquiring attraction as a strategy for increasing energy security. This study aims to optimize the production of ethanol from cassava peel using Box Bhenken experimental design. The total carbohydrate content of about $90 \%$ in cassava peel was subjected to enzymatic hydrolysis using Alpha-amylase followed by Simultaneous Saccharification and Fermentation (SSF) by Saccharomyces cerevisiae for bioethanol production. The production of bioethanol from cassava peels was investigated for 1-4 hours (hydrolysis time), $0.5-1.5 \mathrm{mg} / \mathrm{L}$ (enzyme loading), and 1-5 days (incubation time). A statistical model was developed and validated to predict the yield of bioethanol after fermentation, and the Response Surface Methodology (RSM) was used to optimize the conditions. The results revealed that the maximum ethanol yield of $1.911 \%$ was obtained at the optimum hydrolysis time, enzyme loading, and incubation time (i.e. 2.5 hours, $1 \mathrm{mg} / \mathrm{L}$, and 3 days respectively).
\end{abstract}

DOI: https://dx.doi.org/10.4314/jasem.v24i12.11

Copyright: Copyright (C) 2020 Osemwegie et al. This is an open access article distributed under the Creative Commons Attribution License (CCL), which permits unrestricted use, distribution, and reproduction in any medium, provided the original work is properly cited.

Dates: Received: 19 October 2020; Revised: 29 November 2020; Accepted: 11 December 2020

Keywords: Cassava peel, Optimization, Bioethanol, Modelling

Cassava (Manihot esculenta Crantz) is a shrubby perennial crop in the family of Euphorbiaceae. (Sriroth et al., 2012). Cassava is grown for its edible starchy tuberous root which contains about $94 \%$ carbohydrate and $6 \%$ containing vitamins and proteins. It is extensively produced as an annual crop in tropical countries such as Nigeria, Brazil, Thailand, etc. (Amenaghawon et al., 2014). World production of cassava root was estimated by FAO (2012) to be 230 million tonnes in 2008 with Nigeria accounting for about 54 million tonnes as the world's largest producer of cassava. Large tons of cassava wastes are discarded annually in Nigeria when cassava is processed into various food products (Ozoegwu et al., 2017). These cassava wastes are removed to obtain good quality food products such as fufu, garri, tapioca macaroni, and pudding and also serve as animal feeds. (Bechoff et al., 2018). Unfortunately, these wastes often end up in open dumps or drainage systems which threatens both surface water and general human health condition. It is, therefore, necessary to convert these wastes to useful end products rather than allowing them to become a nuisance to the environment. During the processing of the cassava to obtain food, a solid waste material known as cassava peels are generated. (Amenaghawon et al., 2014), which has been (Prado et al., 2005) identified as a high cellulose material which makes it a potential substrate for the production of value-added products such as organic acids, bioethanol, biopolymers, etc. Bioethanol is a principal fuel that can be used as a petrol substitute for the vehicle. Therefore, this study was initiated to explore the possibility of using cassava peels as a substrate for producing ethanol. Thus this work tends towards investigating the possibility of transforming cassava peels (agricultural waste) to bioethanol, thereby contributing toward alternative energy supply as well as creating employment opportunity. This study is aimed at improving the bioethanol yields from cassava peels through the optimization of its fermentation processes using the Response Surface Methodology (RSM).

\section{MATERIALS AND METHODS}

Lignocellulose Feedstock Collection, Preparation, and Pretreatment: Cassava peels were procured from a local cassava processing plant in Ekosodin, Benin City, Edo State, Nigeria. It was sun-dried for three days before further drying in a preheated oven at 110 ${ }^{\circ} \mathrm{C}$ for 6 hours to reduce its moisture content and prevent biodeterioration. The dried cassava peels were milled into small particles to increase their surface area and make the cellulose readily available for hydrolysis. The dried bagasse was stored under dry conditions before use. Pre-treatment of biomass was performed by measuring $40 \mathrm{~g}$ of cassava peels which were soaked in $0.2 \mathrm{M} \mathrm{NaOH}$. The mixture was hydrothermally pretreated by heating with an autoclave at a temperature of about $120^{\circ} \mathrm{C}$ and for 
about 90 mins. The different pretreated cassava peels slurries were obtained and used for further analysis.

Enzymatic Hydrolysis and Fermentation: The pretreated cassava peel slurries were allowed to cool to room temperature before they were neutralized using hydrochloric acid and then, hydrolyzed by alpha-amylase. Enzymatic hydrolysis was conducted at $55^{\circ} \mathrm{C}$ at different hydrolysis time (1-4) hours. The buffer for hydrolysis was $0.05 \mathrm{M}$ acetate buffer $(\mathrm{pH}$ 4.8). After hydrolysis, the hydrolyzed sampled was used for fermentation for ethanol production. The medium was maintained at $30{ }^{\circ} \mathrm{C}$ inoculated with $5 \mathrm{~g} / 1$ of activated dried yeast (Saccharomyces cerevisiae) at different enzymes loading in a flask and incubated at room temperature for 1-5 days. The percentage of ethanol yield (M) was determined as shown in equation (1):

$$
M=\frac{N}{P}
$$

For the percentage of the ethanol measured in the sample $(\mathrm{N})$, a refractometer will be used to determine the amount $(\%)$ of ethanol concentration $(\mathrm{P})$ present in the sample, given in equation (2) (Nutawan et al., 2010):

$$
\mathrm{P}=\mathrm{R} \times 0.5
$$

Where $\mathrm{R}$ is the amount of initial sugar concentration in fermentation solution (\%)

Experimental Design for Bioethanol Production: A three-variable Box-Behnken Design (BBD) for RSM was used to develop a statistical model for the fermentation process. This is because there was a need to determine the optimum variable combination that could give the desired output with a minimum number of the experiment, without the need for studying all possible combination experimentally. The less number of experimental design points reduced the cost of experiment and optimization processes. The levels of variables optimized are shown in Table 1.

Table 1: Coded and actual levels of the factors for four-factor Box-Behnken Design
\begin{tabular}{ll|l|l|l|l|l} 
Variables & Units & Symbols & \multicolumn{4}{|c|}{ Soded and actual levels } \\
\hline & & & -1 & 0 & +1 \\
\hline & Hydrolysis time & Hours $\mathrm{X}_{1}$ & 1 & 2.5 & 4 \\
Enzymes Loading & $\mathrm{mg} / \mathrm{L}$ & $\mathrm{X}_{2}$ & 0.5 & 1.0 & 1.5 \\
Fermentation Time & Days & $\mathrm{X}_{3}$ & 1 & 3 & 5 \\
\hline
\end{tabular}

This design is suitable for exploring quadratic response surfaces and construction of a secondorder polynomial model (Amenaghawon et al., 2014), the response of the surface to the various variables was used in optimizing the process using several experimental runs. The number of experimental runs is given by equation (3):

$$
N=K^{2}+K+C_{P}
$$

Where $K$ is the factor number and $c_{p}$ replicate the number of the central point. Design Expert ${ }^{\circledR}$ 7.0.0 (Stat-ease, Inc. Minneapolis, USA), statistical software used to develop the experimental design. The coded and actual values of the independent variables were calculated as shown in equation (4):

$$
x_{i}=\frac{X_{i}-X_{o}}{\Delta X_{i}}
$$

Where $x_{i}$ and $X_{i}$ are the coded and actual values of the independent variable respectively. $X_{o}$ is the actual value of the independent variable at the center point and $\Delta X_{i}$ is the step-change in the actual value of the independent variable. The generalised second-order polynomial equation as shown in equation (5), was adopted as a statistical model to estimate the response of the dependent variable (i.e. ethanol yields are obtained). This is because a linear model is insufficient for a mathematical description with adequate precision. That is, a linear model is prone to showing a high error value.

$$
\begin{aligned}
Y_{i}=b_{o}+\sum b_{i} X_{i} & +\sum b_{i j} X_{i} X_{j}+\sum b_{i i} X_{i}^{2} \\
& +e_{i}
\end{aligned}
$$

Where $\mathrm{Bi}$ is the linear coefficient, Bii is the quadratic coefficient, $\mathrm{Bij}$ is the second-order term, $Y_{i}$ is the predicted response or dependent variable, $X_{i}$ and $X_{j}$ are the independent variables, $b_{o}$ is the offset term, $b_{i}$ and $b_{i j}$ are the single and interaction effect coefficients and $e_{i}$ is the experimental error term (Amenaghawon et al., 2013).

\section{RESULTS AND DISCUSSION}

Modelling and Optimization of Response: The coded and actual value of the factors X1 (Hydrolysis time, hours.), X2 (Enzymes Loading, $\mathrm{mg} / \mathrm{L}$ ) and X3 (Incubation time, days) as designed by design expert 7.0 and their corresponding responses are shown in Table 2: 
Table 2: Three-level factorial Box-Behnken design and experimental responses of the dependent variable Y (Ethanol yield, \%), RSM

\begin{tabular}{l|llll|l|l|l|l}
\multicolumn{8}{c}{ predicated responses } \\
\hline \multirow{2}{*}{$\begin{array}{l}\text { Run } \\
\text { No. }\end{array}$} & \multicolumn{3}{l}{$\begin{array}{l}\text { Coded values of } \\
\text { factors }\end{array}$} & \multicolumn{2}{l}{$\begin{array}{l}\text { Actual values of } \\
\text { factors }\end{array}$} & \multicolumn{2}{l}{ Responses (\%) } \\
\cline { 2 - 9 } & X1 & X2 & X3 & X1 & X2 & X3 & Actual & RSM predicated \\
\hline 1 & 0 & 0 & 0 & 2.5 & 1.0 & 3.0 & 1.899 & 1.78 \\
2 & 1 & -1 & 0 & 4.0 & 0.5 & 3.0 & 1.764 & 1.78 \\
3 & 1 & 1 & 0 & 4.0 & 1.5 & 3.0 & 1.799 & 1.85 \\
4 & 0 & -1 & 1 & 2.5 & 0.5 & 5.0 & 1.701 & 1.83 \\
5 & 0 & -1 & -1 & 2.5 & 0.5 & 1.0 & 1.399 & 1.41 \\
6 & 0 & 0 & 0 & 2.5 & 1.0 & 3.0 & 1.851 & 1.39 \\
7 & 0 & 0 & 0 & 2.5 & 1.0 & 3.0 & 1.899 & 1.73 \\
8 & 0 & 1 & 1 & 2.5 & 1.5 & 5.0 & 1.799 & 1.71 \\
9 & 1 & 0 & -1 & 4.0 & 1.0 & 1.0 & 1.421 & 1.41 \\
10 & -1 & 0 & -1 & 1.0 & 1.0 & 1.0 & 1.399 & 1.45 \\
11 & -1 & 0 & 1 & 1.0 & 1.0 & 5.0 & 1.699 & 1.70 \\
12 & -1 & 1 & 0 & 1.0 & 1.5 & 3.0 & 1.867 & 1.79 \\
13 & 0 & 0 & 0 & 2.5 & 1.0 & 3.0 & 1.901 & 1.89 \\
14 & 0 & 1 & -1 & 2.5 & 1.5 & 1.0 & 1.45 & 1.89 \\
15 & 1 & 0 & 1 & 4.0 & 1.0 & 5.0 & 1.72 & 1.89 \\
16 & 0 & 0 & 0 & 2.5 & 1.0 & 3.0 & 1.911 & 1.89 \\
17 & -1 & -1 & 0 & 1.0 & 0.5 & 3.0 & 1.811 & 1.89 \\
\hline
\end{tabular}

Table 2 shows the observed value of the experiment. It can be seen that maximum ethanol yield was $1.911 \%$ and was observed at hydrolysis time of 2.5 hours, enzyme loading of $1.0 \mathrm{mg} / \mathrm{L}$, and an incubation time of 3 days.

Determination of Appropriate Model: The investigation was carried out on linear, cubic, twofactor interaction, and quadratic models to determine the best model that is statistically significant and best describes the relationship between the response and the inputs (independent variables). From the model summary statistics shown in Table 3 , it is seen that the quadratic model has the maximum predicted and adjusted $\mathrm{R}^{2}$ value. Thus, it can be concluded that the quadratic model bests describe the relationship between the response and the independentvariables.

Table 3: Model summary statistics.

\begin{tabular}{l|l|l|l|l|l}
\hline Source & Std. Dev. & R-squared & $\begin{array}{l}\text { Adjusted } \\
\text { R-squared }\end{array}$ & $\begin{array}{l}\text { Predicted } \\
\text { R-squared }\end{array}$ & Press \\
\hline Linear & 0.17 & 0.3603 & 0.2127 & -0.0902 & 0.61 \\
2FI & 0.19 & 0.3615 & -0.0216 & -1.2462 & 1.27 \\
Quadratic* & 0.030 & 0.9892 & 0.9753 & 0.8838 & 0.066 \\
Cubic & 0.024 & 0.9961 & 0.9842 & & + \\
\hline
\end{tabular}

Analysis of Variance (ANOVA): Regression analysis was performed to fit the response. The model developed represents ethanol yield $(\mathrm{Y})$ as a function of hydrolysis time $\left(\mathrm{X}_{1}\right)$, enzyme loading $\left(\mathrm{X}_{2}\right)$, and incubation time $\left(\mathrm{X}_{3}\right)$. The model is given by equation (6) in terms of the actual factors.

$$
\begin{gathered}
Y=074415+0.12286 X_{1}+0.26005 X_{2}+0.48317 X_{3}-0.0073 X_{1} X_{2}-0.00833 X_{1} X_{3}+0.011750 X_{2} X_{3}-0.024322 X_{1}^{2}-0.10890 X_{2}^{2} \\
-0.069431 X_{3}^{2}
\end{gathered}
$$

The second-order polynomial (equation 6) was used to calculate the predicted responses presented in Table 2. A comparison of the predicted values with the responses obtained from the experiment shows a little deviation which mean that there is high extent of correspondence. The significance of fit for the second-order polynomial for the ethanol yield was investigated by carrying out an analysis of variance (ANOVA) as shown in Tables 4 and 5. The model $\mathrm{F}$ value of 71.12 and very low $p$-value $(<0.0001)$ implies that the investigated process variables significantly influenced the output. Since all the terms in a regression model aren't equally important, the p-value is used to check the significance of each coefficient. The "lack of fit" F value of 2.329 implies that there was an insignificant lack of fit. The authenticity of the model was assessed through the lack of fit test. The Pvalues for the lack of fit test was not significant ( $P>0.05)$ demonstrating that the model was fit for predicting the ethanol yield. The coefficient of variation $(\mathrm{CV})$ obtained was $1.71 \%$ (Table 5). This value indicates the degree of precision with which the treatments were compared (Qi et al., 2009). The relatively low value of $\mathrm{CV}$ obtained showed that the treatments were carried out with high precision and reliability (Montgomery, 2005; Mason et al., 1989). 
Table 4: Analysis of variance for response surface quadratic model

\begin{tabular}{l|l|l|l|l|l|l}
\multicolumn{6}{c}{ Table 4: Analysis of variance for response surface quadratic model } \\
\hline & $\begin{array}{l}\text { Sum of } \\
\text { Squares }\end{array}$ & Df & $\begin{array}{l}\text { Mean } \\
\text { Square }\end{array}$ & $\begin{array}{l}\text { F } \\
\text { Value }\end{array}$ & $\begin{array}{l}\text { p-value } \\
\text { Prob }>\text { F }\end{array}$ & \\
\hline Model & 0.5577 & 9 & 0.062 & 71.12 & $<0.0001$ & Significant \\
$\mathrm{X}_{1}$ & 0.0006 & 1 & 0.0006 & 0.744 & 0.4171 & \\
$\mathrm{X}_{2}$ & 0.0072 & 1 & 0.0072 & 8.263 & 0.0238 & \\
$\mathrm{X}_{3}$ & 0.1953 & 1 & 0.1953 & 224.1 & $<0.0001$ & \\
$\mathrm{X}_{1} \mathrm{X}_{2}$ & 0.0001 & 1 & 0.0001 & 0.127 & 0.7325 & \\
$\mathrm{X}_{1} \mathrm{X}_{3}$ & $2 \mathrm{E}-07$ & 1 & $2 \mathrm{E}-07$ & $3 \mathrm{E}-04$ & 0.987 & \\
$\mathrm{X}_{2} \mathrm{X}_{3}$ & 0.0006 & 1 & 0.0006 & 0.634 & 0.4521 & \\
$\mathrm{X}_{1}{ }^{2}$ & 0.0126 & 1 & 0.0126 & 14.47 & 0.0067 & \\
$\mathrm{X}_{2}{ }^{2}$ & 0.0031 & 1 & 0.0031 & 3.581 & 0.1003 & \\
$\mathrm{X}_{3}{ }^{2}$ & 0.3248 & 1 & 0.3248 & 372.7 & $<0.0001$ & \\
Residual & 0.0061 & 7 & 0.0009 & & & not \\
& & & & & & significant \\
Lack of Fit & 0.0039 & 3 & 0.0013 & 2.329 & 0.2159 & \\
Pure Error & 0.0022 & 4 & 0.0006 & & & \\
Cor Total & 0.5638 & 16 & & & & \\
\hline
\end{tabular}

An Adequate precision value of 21.97 was obtained. Cao et al. (2009) reported that adequate precision gives an indication of the signal-to-noise ratio and suggested that a value greater than 4 is generally desired. The value of 21.97 obtained indicates an adequate signal and the model can be used to navigate the design space. The coefficient of determination $\left(R^{2}\right)$ was obtained as 0.989 . This indicated that the model satisfactorily represents the relationship between the independent variables (hydrolysis time, enzyme loading, and incubation time) and the response (ethanol yield). The $\mathrm{R}^{2}$ value indicates that $98.9 \%$ of the variability in the response could be explained by the statistical model, while $1.1 \%$ could not be accounted for by the independent variables (Amenaghawon et al., 2014). The $R^{2}$ value indicates the degree to which the model was able to predict the response. The closer the $R^{2}$ value is unity, the better the model can predict the response (Qi et al., 2009). The "Predicated R-Squared" of 0.8838 is in reasonable agreement with the "Adjusted R-Squared" of 0.9753, that is, the difference is less than 0.2 .

Table 5: Statistical information for ANOVA

\begin{tabular}{l|l}
\hline Parameter & Value \\
\hline Standard deviation & 0.03 \\
Mean & 1.723 \\
C.V. \% & 1.71 \\
PRESS & 0.07 \\
R-Squared & 0.989 \\
Adj R-Squared & 0.975 \\
Pred R-Squared & 0.884 \\
Adeq Precision & 21.97 \\
\hline
\end{tabular}

Parity Plot: The actual and predicted responses shown in Table 2 were plotted to analyze the correlation between them as shown in Figure 1. It is observed from the plot that the data points are distributed near the straight line. This further indicates that the quadratic model could be employed as a significant model for predicting response over the independent input variables.

Optimization of Ethanol Fermentation of Cassava Peels: Response surface curves were plotted to examine the effect of the interaction between the independent variables and to determine the optimum levels of the variables. To determine the optimal levels of the independent variables affecting the ethanol yield from cassava peels, three-dimensional (3D) response surface and contour plots were constructed according to the regression model. The $3 \mathrm{D}$ plots were generated by keeping two factors at their optimum point and varying the other two factors within their experimental ranges. The plots show how hydrolysis time, enzyme loading, incubation time affects the ethanol yield. The contour plot may be rising ridges, saddle point, elliptical or circular plot. A circular or elliptical plot indicates that there exists a significant interaction between the operating parameters (Kanmani et al., 2013).

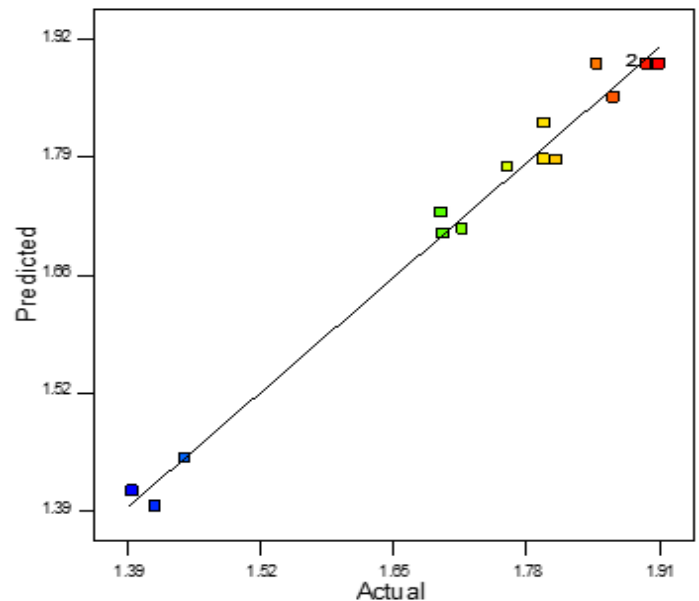

Fig 1: Parity plot of predicted values against actual values of ethanol yield 
Analysis of Response Surface Plots. A. Interaction between hydrolysis time, enzymes loading, and ethanol yield: The effect of hydrolysis time and enzyme loading on the ethanol yield is shown in Figure 2. It was observed that an increase in hydrolysis time and also an increase in enzyme loading, increased ethanol yield. The plot showed that the enzyme loading had a significant effect on the ethanol yield within the range of hydrolysis time investigated (1-4 hours). If the enzyme loading is too high, a problem with enzyme accessibility could inhibit the conversion of cellulose. The increasing of viscosity material could also affect to reduce enzyme mobility. The longer the hydrolysis time, the more cellulose is converted into simple glucose so that when a lot of simple glucose fermentation process can be converted by saccharomyces cerevisiae into bioethanol, but an extension of the hydrolysis time, ( $>2.5$ hours.) can negatively affect the degree of saccharification, probably due to enzymes denaturation. The maximum ethanol yield was obtained at an enzyme loading of 1.0 $\mathrm{mg} / \mathrm{L}$ and a time of about 3 hours hydrolysis time. It can be observed that any further increase in time leads to a decrease in the ethanol yield. A similar result was reported by (Betiku and Taiwo, 2015) who reported optimum enzyme loading is a ratio of $1.0 \mathrm{mg} / \mathrm{L}$ for the production of ethanol from breadfruit starch hydrolysate. Similarly, (Hajar et al., 2012) reported an optimum enzyme loading of $1.5 \mathrm{mg} / \mathrm{L}$ during a hydrolysis time of 2.5 hours to obtain an ethanol yield of $1.93 \%$ from pineapple peel extract.
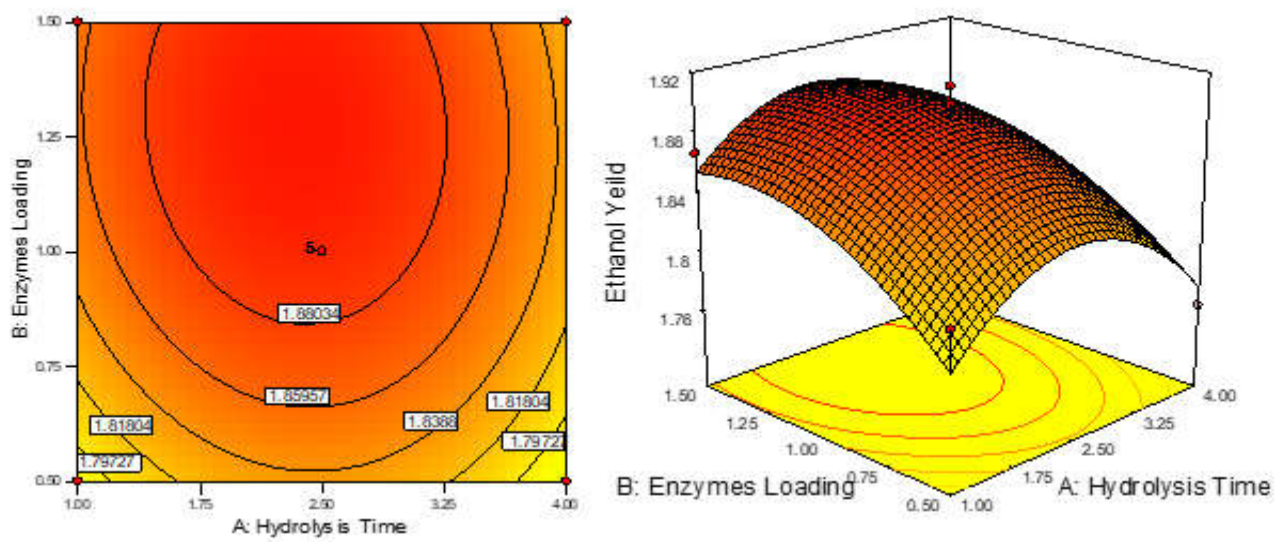

Fig 2: Response surface plot and corresponding contour plot of the simultaneous effect of hydrolysis time and enzyme loading on the ethanol yield.

B. Interaction between hydrolysis time, incubation time, and ethanol yield: Figure 3 shows the interactive effect of hydrolysis time and incubation time. It was observed that an increase in incubation time and hydrolysis time leads to an increase in ethanol yield. The production of ethanol starts after the lag phase of about 1 hour and reached a maximum of about 3 hours. As the fermentation keeps on going longer, the ethanol production became stagnant or even decreased. This might be caused by the formation of inhibitory compounds, such as furfural, acetic acid, and phenolic. Phenolic compounds are produced from partial lignin damage, which could occur during a pretreatment process. This corresponds to the low delignification degree, hence the remains of the pretreatment process caused inhibition. During fermentation, a decrease in ethanol could also be caused by the composition of the substrate, reduction of the enzyme's active sides, and the inefficiency of mass transfer. A similar result was reported in a previous study (Nanssou et al., 2016) who reported an optimum incubation time of 3 hours was observed for the production of ethanol from plantain peel.

C. Interaction between enzymes loading, incubation time, and ethanol yield: Figure 4 illustrates the effect of enzyme loading and incubation time on ethanol yield. It was observed that an increase in enzyme loading, increase in incubation time leads to an increase in ethanol yield. At low incubation times, the ethanol yield increased slowly with an increase in enzyme loading from $0.5 \mathrm{mg} / \mathrm{L}$ to $1.5 \mathrm{mg} / \mathrm{L}$. For the range of enzyme loading investigated, intermediate levels of the time were needed to obtain a high ethanol yield, and any further increase in time resulted in a decrease in ethanol yield. The maximum ethanol yield of about $1.911 \%$ was obtained at an incubation time of about 3days and enzyme loading of about $1.0 \mathrm{mg} / \mathrm{L}$. Shanavas et al. (2011) reported the optimum yield of ethanol from cassava starch was $2.0 \%$ using an enzyme loading of $1.0 \mathrm{mg} / \mathrm{L}$ and a reaction time of 180 mins. 

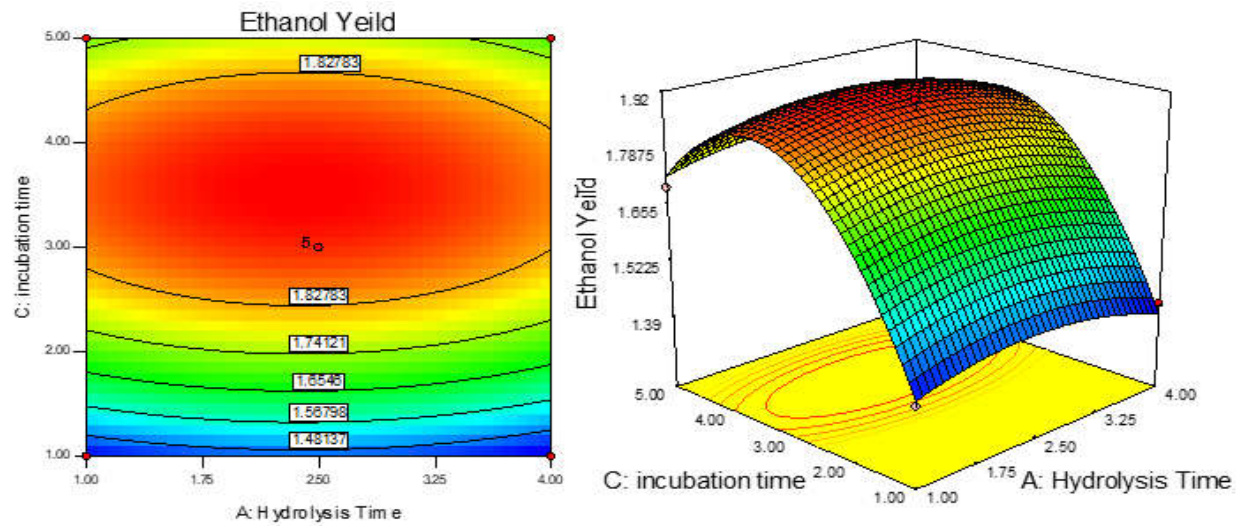

Fig 3: Response surface plot and corresponding contour plot of the simultaneous effect of hydrolysis time and incubation time on the

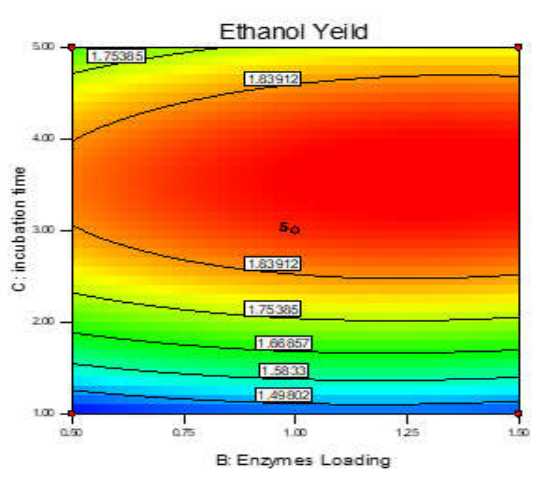
ethanol yield

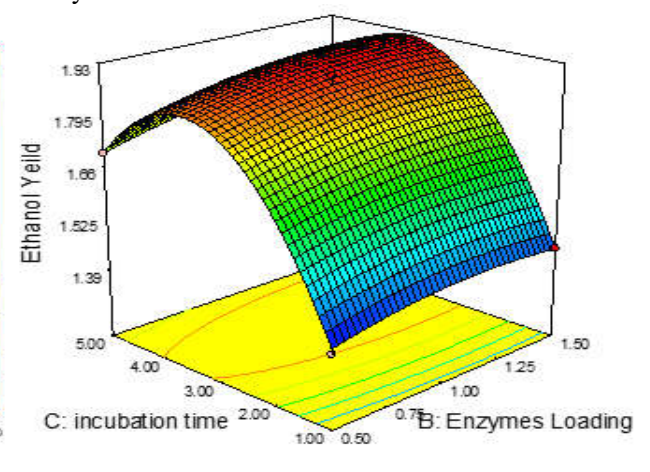

Fig 4: Response surface plot and corresponding contour plot of the simultaneous effect of enzymes loading and incubation time on the ethanol yield

Numerical Optimization: Figure 5 below, shows that hydrolysis time, enzyme loading, and incubation time were optimized based on the model developed by each response. The maximum ethanol yield from cassava

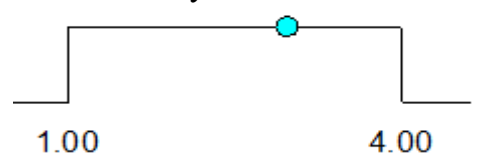

Hydrolysis Time $=2.99$

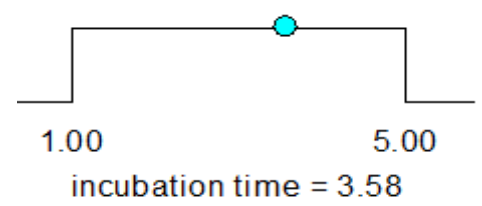

predicted by the model was $1.913 \%$. The optimal hydrolysis time, enzymes loading and incubation time were 2.9 hours, $1.42 \mathrm{mg} / \mathrm{L}$, and 3.58 days respectively.

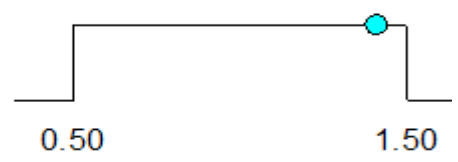

Enzymes Loading $=1.42$

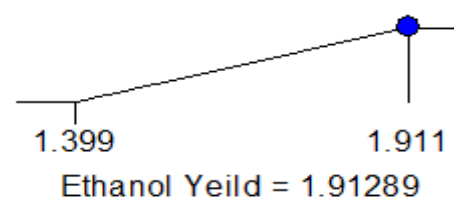

\section{Desirability $=1.000$}

Fig 4: Ramp numerical optimization of response

Validation of Statistical Model: To confirm the validity of the statistical model, three confirmation experimental runs were performed at the chosen optimum fermentation conditions. The result shows that the maximum experimental ethanol yield of $1.911 \%$ obtained was close to the predicted value of $1.913 \%$. The excellent correlation between the predicted and measured values of these experiments shows the validity of the statistical model.

Conclusions: This study investigated the performance of RSM on the modeling and optimization of the three variables (hydrolysis time, enzyme loading, and incubation time) on ethanol production from cassava peels. A significant quadratic model 
$(\mathrm{p}<0.05)$ has been obtained to predict the concentration of ethanol yield as a function of the three input factors using RSM. Further investigation into the use of cassava peels for bioethanol production is required. Also, more agro-waste products are needed to check for their usability for producing value-added products.

\section{REFERENCE}

Amenaghawon, NA; Nwaru, KI; Aisien, FA; Ogbeide, SE; Okieimen, CO (2013). Application of BoxBehnken Design for the optimization of citric acid production from corn starch using Aspergillus niger. British Biotech. J. 3(3). 236-245.

Amenaghawon, NA; Ogbeide, SE; Okieimen, CO (2014). Application of Statistical Experimental Design for the Optimisation of Dilute Sulphuric Acid Hydrolysis of Cassava peels. Acta Polytechnica Hungarica, 11(9). 1-12.

Amenaghawon, NA; Okieimen, CO; Ogbeide, SE (2014). Modelling and Statistical Optimization of Dilute Acid Hydrolysis of Eucalyptus Wood Chips using Response Surface Methodology. Pac. J. Sci. Tech. 15(1). 245256.

Bechoff, A (2018). Cassava traits and end-user preference: Relating traits to consumer liking, sensory perception, and genetics: Crit. Rev. Food Sci. Nut. 58(4). 547-567.

Betiku, E; Taiwo, AE (2015). Modeling and optimization of bioethanol production from breadfruit starch hydrolyzate vis-à-vis response surface methodology and artificial neural network. Renew. Energy, 74. 8794.

Cao, NJ; Krishnan, MS; Gong, CS; Ho, NW; Tsao, GT (1996). Ethanol production from corn cob pretreated by ammonia steeping process using genetically engineered yeast. Biotech. Let. 18. 1013-1018.

FAO (Food and Agricultural Organization) of United Nations (2012). Annual Statistics, Rome, Italy.

Hajar, N (2012). Optimization of Ethanol Fermentation from Pineapple Peel Extract Using Response Surface. World Acad. Sci. Eng. Tech. 6(12). 641-647.

Kanmani, P; Kathik, S; Aravind, J; Kumaresan, K (2013). The use of response surface methodology as a statistical tool for media optimization in lipase production from the dairy effluent isolate Fusarium solani. ISRN Biotechnology. Article ID: 528708:8.

Kongkiattikajorn, J; Sornvoraweat, B (2011). Comparative Study of Bioethanol Production from Cassava Peels by Monoculture and Co-Culture of Yeast. Kasetsart J. Nat. Sc. 45. 268-274.

Mason, RL; Gunst, RF; Hess, JL (1989). Statistical Design and Analysis of Experiments. New York: John Wiley.

Moghaddam, MG; Khajeh, M (2011). Comparison of Response Surface Methodology and Artificial Neural Network in Predicting the Microwave-Assisted Extraction Procedure to Determine Zinc in Fish Muscles. Food and Nut. Sci. 02(08). 803-808.

Montgomery, DC (2005). Design and Analysis of Experiments, $6^{\text {th }}$ Ed. New York. John Wiley and Sons, Inc.

Nanssou, PAK; Nono, YJ; Kapseu, C (2016). Pretreatment of cassava stems and peelings by thermohydrolysis to enhance hydrolysis yield of cellulose in bioethanol production process. Renewable Energy, 97. 252-265.

Ozoegwu, CG; Eze, C; Onwosi, CO; Mgbemene, CA; Ozor, PA (2017). Biomass and bioenergy potential of cassava waste in Nigeria: Estimations based partly on rurallevel garri processing case studies. Renew. Sustain. Energy Rev. 72 (C). 625-638.

Prado, FC; Vandenberghe, LP; Woiciechowski, AL; Soccol, R (2005). Citric acid production by solid-state fermentation on a semi-pilot scale using different percentages of treated cassava bagasse. Brazilian $J$. Chem. Eng. 22(4) 1-14.

Qi, B; Chen, X; Shen, F; Wan, Y (2009): Optimization of Enzymatic Hydrolysis of Wheat Straw Pretreated by Alkaline Peroxide Using Response Surface Methodology. Indust. Eng. Chem. Res. 48. 7346-7353

Shanavas, S (2011). Process optimization for bioethanol production from cassava starch using novel ecofriendly enzymes. Biomass and Bioenergy, 35(2). 901909.

Sriroth, K; Wanlapatit, S; Piyachomkw, K (2012). Cassava Bioethanol. Bioethanol, Marco Aurelio Pinheiro Lima and Alexandra Pardo Policastro Natalense, IntechOpen, DOI: $\quad 10.5772 / 23112$. Available from: https://www.intechopen.com/books/bioethanol/cassava-bioethanol.

Woiciechowski, AL; Nitsche, S; Pandey, A; Soccol, CR (2002): Acid and Enzymatic Hydrolysis to Recover Reducing Sugars from Cassava Bagasse. Brazilian Arch. Bio. Tech. 45. 393-400.

Yoswathana, N; Phuriphipat, P; Treyawutthiwat, P; Eshtiaghi, MN (2010). Bioethanol Production from Rice Straw. Department of Chemical Engineering, Faculty of Engineering, Mahidol University, Thailand Publications, 1(1). 26-31. 